\title{
ANTI-COMMUNISM AND THE STRUgGLE FOR THE RENEWAL OF COMMUNISM ${ }^{1}$
}

\author{
TYMOTEUSZ KOCHAN
}

The primary area of exclusion that anti-communism generates is located in social education. It is the actively anti-communist upbringing offered by the contemporary education system that translates into later anti-communist hegemony - first cultural, then political.

The exclusion results here from the total domination of extreme right-wing politics, which is intertwined with the pseudo-neutrality of the markets. Workers do not receive any choice, because the only universal socialization approved by the ideological apparatus of the state is precisely this anti-communist one. Such a system of universal education effectively creates a man faithful to capitalist values and opposing everything related to communism. Media and institutions unfavourable to communism kill every potential worker's desire for change, while the selection procedures present in education divide people by their class origin and economic status, and do not favour the formation of elites with a different worldview than pro-system and anti-communist.

Every type of capitalism thrives on the mystification of class relations and the misrepresentation of truths regarding the power relations within the economy. Polish capitalism is still extraordinarily uncertain and continually struggles with the experience of real socialism, which in some aspects still allows us to believe in the existence of any systemic alternative. The uncertainty of the prevailing order translates into the aggression and strength

\footnotetext{
${ }^{1}$ The title comes from the editors.
} 
of the means used by the state apparatus. The fight against communism is carried out with the use of significant financial resources and by stigmatising everyone who expresses any interest in the matter of non-capitalist reality. Hence the powerful and aggressive cult of anticommunist heroes and the anti-communist version of politics of history, hence entrepreneurship lessons at schools instead of labour law, and hence child-raising in the spirit of nationalist militias. Hence the constant pressure of the conservative and profoundly anticlass vision of society, which also requires religious sauce, elevating to the rank of sainthood the idea of the great national community that includes national bourgeoisie and representatives of at least the national sphere of finances.

This excludes the world of work and labour as a class subjectivity while simultaneously forging an entirely new man who actively fights against the enemy system, and who cannot see himself beyond the world of private property and the imaginary it implies.

The essential driving force of the anti-communist ideology, therefore, remains above all the bourgeois ideology embedded deeply into social consciousness, without which the system's expropriation of 90 percent of society would never be able to arise and function. What has long been seen as common sense in Marxist philosophy is that the individualist and free-market ideology in its spectrum of influence is not limited to the capitalist class itself, but primarily serves to disintegrate the workers' sense of class solidarity and identity, without which communist thinking and the communist project itself becomes completely impossible. This exclusion of workers is above all their active alienation from an independent class politics, which in certain imperialist conditions, however, does not necessarily bring them only failures. This does not change the fact that workers themselves mostly do not believe today that they are workers belonging to a particular class, because the sense of belonging to the working class is a cause of shame, a symptom of defeat and being a "loser", waste of the capitalist rat race.

The ruling classes of late capitalism are perfectly aware of the fact that they participate in class struggle, and they also know that the best way to safeguard their rule is to undermine faith in all alternatives, especially now, in the era of the coming capitalist economic crisis and the climate disaster caused by the mode of capitalist production.

The dominated classes, on the other hand, live by their newly acquired faith in a chance, as well as by a comical belief in fairy tales about national community and society, which will eventually grow up to become one big loving family. Living with such a capital-sponsored imagination is being a spontaneous servant of the system, an eternally individualised human capital, and being convinced of participation in a continuous progression towards the achievement of private property.

This eternal and never-fulfilled struggle for wealth is also naturally related to existence in semi-peripheral capitalism, where the chances of acquiring even small resources to liberate 
oneself from the ubiquitous exploitation of capital are still such an active illusion that they constitute an actual object of worship and a distinctive landmark for the popular identity.

This exceptionally enticing but completely impossible opportunity for acquiring capital produces a first anti-class and then anti-communist identity. At the same time, such identity implies a reluctance to fraternise with representatives of any class, especially with other representatives of the working class who are already mainly seen as active market competitors. Class in itself today alienates workers from the very possibility of use of the fruits of capital. Thinking about a world without owners (read - the noble "employers") or even being a member of a trade union becomes in this situation a harmful and deeply self-destructive act.

Another ally of anti-communism is a resurgent narrative about the national and ethnic community, which is nothing but the prolongation of cultural racism resulting from the competition between nations and regions of the world. This narrative makes anti-communism as a worldview more powerful, and strengthens the forms of identity based on national, ethnic and territorial unity. It does so because communism itself is a real threat, both to all visions of national communities and their supremacy, and to the claims of global capital for the right to be the only "internationalism", acting above the structures of individual nations and being the main beneficiary of the death of the communist project.

The exclusion from class follows precisely as the result of being interpellated into the national community.

The crucial question to be answered is whether the communist project would, at the moment, improve the consumption share of the contemporary Western proletarian, because it is this aggressive consumer consciousness that is currently the most painfully cognitively exclusive factor. In the utopia of eternal welfare based on the conditions of Western domination, the utopia of eternal economic growth and the reign of mass consumer culture, anti-communism is the only reasonable option and obligation. Being excluded from the communist project and mobilised to fight against it is a disaster for a citizen of peripheral and semi-peripheral capitalism. It is also a disaster for the future of all humankind. Yet even for the worker from the very heart of the Empire, it is still a conscious decision, the importance of which should not be underestimated.

As for the effective fight against anti-communism, it is not yet possible. Certainly not as long as it is merely a "fight against anti-communism".

Being a defender of the communist cause, which by the ideological apparatus of the capitalist state has already been thoroughly and very effectively assigned to Stalinism, hunger in Ukraine and lumpen-anti-socialist aesthetics derived from Netflix's "1983" series, is doomed to failure. The decisive voice will always belong here to the cultural means of reproduction, which are still owned by the capitalist elites, who, regardless of whether they are liberal or nationalist, will always be jointly anti-communist. 
This leads to a simple conclusion that the progressive forces advocating for a positive vision of communism of any type, either in Poland or in Europe and the rest of the world, do not have the tools and means to regain the communist project while fighting on conditions that have already been arranged by the global hegemony of capital. The recovery of communism is not possible in the same sense that it is impossible to regain the charm of peasant revolts or the savour of Bolshevism.

In order to become truly recovered, communism must first be rejected in its past form and then renewed, especially through a spread in mass consciousness.

To a certain extent, we have already made this step, but still, new forms of resistance have not been transformed into an effective movement, especially in the wealthiest part of the world. Communism has yet to be called a new movement when it will become real communism.

On the active side, it is primarily about rejecting all historical fetishes and longings for the $19^{\text {th }}$ and $20^{\text {th }}$ century aesthetics. The communist movement of the past has never been a struggle for history and concepts for themselves. True communism is a movement that strives for the positive abolition of the present state of affairs, based on the principles that were only generally marked out by the Marxist tradition. Communism will be wholly defeated as long as its defenders are activists and theoreticians too attached to the old colours, symbols and ideas, deprived of the ability to adapt constantly.

Movement requires constant changes, and the fight against anti-communism only makes sense when it is combined with a fight for a realistic, new, universal project which has at a particular moment both the political load of a certain mass and a real chance for success. Communism, understood as the abolition of classes and the socialised mode of production, can also be realised in many ways, and as a political project, it is primarily owned by the global proletariat and its communal interests.

Therefore, if the new, real communism cannot be either the former communism or merely a victory over anti-communist politics of history, then the focus should primarily be on developing a vision of what the modern and innovative communism could be. Such a project is already palpable, and it is becoming clear that the new communism will be primarily a challenge of humanity's survival in the face of climate-change-driven extermination, as well as in the face of a great regressing into imperialist nationalisms and the ever-increasing threat of war. Anti-anti-communism of the present day is a new project for and by the workers, and activism is a struggle for collective survival, which we will not achieve without getting rid of the disease, which is global, destructive capitalism.

The real challenge is to initiate the actions of the working class itself, which at the moment, due to the prevailing ideologies, is still mostly indifferent to the fate of communism (because it does not see in it the real representation of its interests), and to the fate of humanity, located on a lethal collision course with the greed of global capital. 
Tymoteusz Kochan (1990) - Marxist philosopher and sociologist, cultural critic and columnist. PhD candidate at the Institute of Philosophy of the University of Szczecin. The editor of the peer-reviewed journal of philosophy "Nowa Krytyka", leader of the "Marxist Critique Group" and the editor-in-chief of the Marxist website "Socjalizm Teraz". Member of the organising committee of the interdisciplinary academic conference organised by the journal "Nowa Krytyka" and the University of Szczecin on the 200"th Anniversary of the birth of Karl Marx and devoted to his philosophical oeuvre. The conference was illegally interrupted by the police intervention at the conference university's venue.

Citation: Kochan, Tymoteusz. 2019. “Anti-Communism and the Struggle for the Renewal of Communism” Praktyka Teoretyczna 1(31): 169-173.

DOI: $10.14746 /$ prt.2019.1.9 